somewhat among the elements of the subjacent tissues (muscular fibres and connecivive cells). It is thus that, by successive appositions of new parts issuing from the pedal fissure, the striæ are formed, of which only the most salient are visible to the naked eye or the lens.

On the other surface of the operculum we must distinguish two regions, the surface of insertion of the columellar muscle, and the free internal surface. It is very easy to see that the free inner surface and the outer surface of the operculum have not the same constitution. The inner surface is covered with a homogeneous layer which forms, as it were, a varnish without any striæ perceptible to the eye. This coating may even be so thick that we cannot see through it the strix of the other surface (Murex). In other cases it is delicate enough not to hide them (Littorina, Trochus). This difference of constitution arises from a difference of origin. In front of the surface of insertion the metapodium forms an anterior expansion or lip, which, during the life of the animal, is constantly applied against the inner unattached part of the operculum. The epithelial cells of this anterior lip produce the varnish.

It still remains to ascertain why the opercular material is rolled into a spiral. To elucidate this point we must study the muscular impression. As the operculum grows, the surface of insertion of the operculum is displaced with a slight movement of rotation, since during the same time the shell grows in a spiral. The muscle attaches itself to the newly formed parts, abandoning the old parts on the side of the parietal margin. These stages of the columellar muscle are marked by striæ independent of those of the superior surface. We observe them when preparing an operculum after removing all traces of muscle. By studying these lines we can even understand why there are opercula of which the form always remains the same, while there are others of which the form varies with the age of the animal. The latter are said to have a nucleus of formation. The posterior secreting portion of the foot always retains the same form in the first case, whereas in the second we see it from nearly circular become almost straight.

Thus we see that the operculum is a production of a definite portion of the epithelium of the foot, and appears to be very different from the byssus of the Acephala, which is produced by a highly developed gland occupying a good part of the volume of the foot. It is still more different from the second valve of a shell.Comptes Rendus, January 28, 1884, p. 236.

\title{
A Fungus infesting Flies.
}

Prof. Leidy directed attention to a vial filled with flies adherent to fragments of leaves. He stated that on the 1st of August, the last summer, he had noticed that from the swarm of flies that were attracted by the ripe fruit of a black mulberry, Morus nigra, many settled on the underside of the leaves, and there became fixed and died from the invasion of a fungus, in the same manner as the 
house-fly often becomes attached to walls and window-panes, in the autumn, through the agency of the fungus known as the Sporendonema. The infested flies on the mulberry-tree were so numerous, that perhaps a fourth of the foliage of the lower boughs had from one to half a dozen of the flies adherent to each leaf. The fly, though a familiar one, is unknown by name to him. It resembles the house-fly, but is larger and has a black abdomen, with lateral whitish spots. The fungus, of a fuscous hue, is especially evident in the extended intervals of the segments of the abdomen, along the sides of the thorax, and at the nock. Though extending to and attaching the flies to the leaves, the specimens no not exbibit the zone of spores on the leaf, as commonly seen in those of infested house-flies. Microscopic examination exhibited a similar structure of the fungus to that of the Sporendonema or Empusa muscee. It mainly consists of translucent cylindrical, straight or somewhat tortuous rods or tubes of variable length with rounded ends, and containing homogeneous liquid with rows of oil-like globules. Mingled with the tubes are numerous oval, ovoid, and pyriform spore-like bodies, usually each with two oil-like globules. The spore-like bodies measure 0.028 to 0.036 millim. long by 0.016 millim. thick. The longer tubes measure usually up to 0.16 millim. long by 0.012 millim. thick.-Proc. Acad. Nat. Sci. Philad., Dec. 1883 , p. 302.

\section{On the Occurrence of Colobus Kirkii.}

We have received the following communication from Sir J. Kirk regarding this monkey; it is dated from Zanzibar, Feb. 16th :-

"In the Proc. Zool. Soc. Feb. 1868, p. 27, Dr. Gray described a new Colobus, and named it after me. That monkey then was rare, but still to be had in many of the wooded districts of this island. I am not aware that it has been found in Pemba Island or on the mainland; and now I discover that, if not extinct, it has become so rare as not to be procurable, even when I sent the hunters over the islaud. I have a report that it exists still in one spot which they could not reach. I think two specimens were sent to Germany some time ago ; but it looks as if the animal will be lost. This is due to the destruction of forest and jungle over the island."

\section{Polythalamia from Inland Salt Water in Hungary. By Dr. Eugen von Daday.}

The author has found, in a mass collected from a salt pool near Déva, in Transylvania, examples of Polythalamia, the shells of which show no traces of calcification, but consist of a yellowish chitinous substance, on the surface of which numerous little plates of quartz adhere. Probably the Polythalamia found near Déva are the representatives of a living continental species; but the author leaves this to be settled by further investigation.-Math. naturwiss. Berichte aus Ungarn, Bd. i. p. 357. 


\section{$2 \mathrm{BHL}$ Biodiversity Heritage Library}

1884. "A fungus infesting flies." The Annals and magazine of natural history; zoology, botany, and geology 13, 306-307. https://doi.org/10.1080/00222938409459241.

View This Item Online: https://www.biodiversitylibrary.org/item/88062

DOI: https://doi.org/10.1080/00222938409459241

Permalink: https://www.biodiversitylibrary.org/partpdf/64959

\section{Holding Institution}

Smithsonian Libraries

\section{Sponsored by}

Smithsonian

\section{Copyright \& Reuse}

Copyright Status: Public domain. The BHL considers that this work is no longer under copyright protection.

This document was created from content at the Biodiversity Heritage Library, the world's largest open access digital library for biodiversity literature and archives. Visit BHL at https://www.biodiversitylibrary.org. 